\title{
INVESTIGATION ON INFLUENCE OF ANIONIC SURFACTANT FOR HOMOGENISATION OF MWCNT IN ALUMINIUM 6065 MATRIX
}

\author{
Savina Jaddinagadhe Puttaswamy* and \\ RAGHAVENDRA BOMMANAHALLI VENKATAGIRIYAPPA \\ Department of Mechanical Engineering, JSS Academy of Technical Education, \\ Bangalore-560060, India \\ *Corresponding author: mailtosavin@gmail.com
}

(Received: $21^{\text {st }}$ December 2019; Accepted: $13^{\text {th }}$ March 2020; Published on-line: 20 $0^{\text {th }}$ July 2020)

\begin{abstract}
In the proposed work, sodium dodecyl sulfate (SDS) is used as a surfactant for carbon nanotubes, to fabricate multi walled carbon nanotube-aluminium metal matrix composites (MMCs). This paper presents the comparison study of SDS coated and non-coated multi walled carbon nanotube (MWCNT) mixed with A16065 by stir casting technique. The presence of low molecular weight surfactant treated with MWCNT was investigated by Fourier Transform Infrared (FTIR) spectroscopy analysis. About 1 wt. \% of MWCNT is used as a filler metal in Aluminium and the dispersion characteristics of SDS coated and non-coated Carbon Nanotubes in the composite is examined using a scanning electron microscope (SEM). The comparison study of SEM analysis showed thatthe MWCNT coated with SDS has good dispersion stability and considerable reduction in agglomeration to obtain agglomeration free composites. The mechanical properties and wear characteristics of the MWCNT-Aluminium matrix were studied as per the American Society for Testing and Materials (ASTM) standards. The results of SDS coated MWCNT exhibits exceptional properties with increase in the tensile strength, compressive strength, hardness, and wear characteristics of the reinforced metal matrix.
\end{abstract}

ABSTRAK:Natriumdodesilsulfat (SDS) digunakan sebagai surfaktan pada karbon nanotiub, bagi menghasilkan multi dinding karbon nanotiub-komposit matriks logam aluminium (MMCs). Perbandingan dibuat dalam kajian ini dengan membandingkan salutan SDS dengan bukan-salutan multi dinding karbon nanotiub (MWCNT) yang bercampur A16065 melalui teknik kacauan acuan. Kahadiran berat surfaktan molekul ringan terawat dengan MWCNT dikaji mengguna pakai analisis spektroskopi Penjelmaan Fourier Inframerah (FTIR). Kira-kira 1 wt.\% MWCNT digunakan sebagai pengisi besi dalam Aluminum dan ciri-ciri penyebaran salutan SDS dan bukan-salutan karbon nanotiub dalam komposit diteliti menggunakan pengimbas mikroskop elektron (SEM). Perbandingan analisis SEM menunjukkan, salutan MWCNT dengan SDS mempunyai kestabilan penyebaran dan berkurang dengan banyak dalam pengaglomeratan bagi mendapatkan komposit bebas pengaglomeratan. Ciri-ciri mekanikal dan haus matrik Aluminium-MWCNT dikaji berdasarkan piawai Persatuan Pengujian Bahan Amerika (ASTM). Keputusan MWCNT salutan SDS mempunyai ciriciri luar biasa dengan kenaikan kekuatan tegangan, kekuatan mampatan, kekerasan, dan ciri-ciri haus pada kekuatan matrik logamn.

KEYWORDS:MWCNT (multi-walled carbon nanotube); aluminium matrix; SDS (sodium dodecyl sulfate); mechanical properties 


\section{INTRODUCTION}

Several manufacturing industries are facing challenges for attaining a stable and uniform dispersion of carbon nanotube (CNT) in a metal matrix [1]. It is important to understand the manipulation of the particles at micro or nano level to accomplish a yield with the desired qualities.

An exponential growth is found in the properties of ceramic, metallic, and polymeric composites with the introduction of CNTs as reinforcements. The improved mechanical properties, including the average elastic modulus within the range of 1 to $2 \mathrm{TPa}$, the tensile strength from $11 \mathrm{GPa}$ to $63 \mathrm{GPa}$, and the integration of CNTs with aluminium-based metal matrix nano-composites (Al-MMCs), has attracted researchers all across the globe. The research mainly focuses on obtaining high thermal stability, good strength to weight ratio, and stiffness with higher electrical conductivity in engineering material applications $[2,3]$.

The aluminium based metal matrix is used as a lightweight component in manufacturing industries and is popular for its low density and high stiffness. Various reinforcing materials like silicon carbide, aluminium oxide, graphite, and CNTs are best suited for aluminium based metal matrix composites. The uniform dispersion of particulate matter along with high stability plays an important role in many industrial applications. Thus, the surface modification and various complementary strategies must be incorporated in order to obtain compatibility between CNTs and aluminium matrices. This will guarantee the homogenous dispersion and will introduce densification in the composite materials [4]. The complexity of dispersion tends to increase when the micro or nano sized particles are injected. Within the specified ranges, the dispersion state of particles in the final product is controlled by the surface chemistry.

The manipulation of surface properties thus becomes important to achieve a product of desired properties. Of the various methods involved, the stir casting method is one of the more prominent and cost effective methods followed by researchers [5]. In this method, the particulate reinforcements are evenly mixed with the molten metal, which is later subjected to solidification. With the help of a rotating impeller, the pre-treated particles are inserted into the vortex of the molten alloy. During this process the issue that arises is sedimentation (also called agglomeration of reinforcements). That is, the reinforcements do not disperse uniformly. The poor dispersion of the reinforcements due to agglomeration with large Van-der Waals forces within the nano tubes and their poor wettability between aluminium and CNTs, are thought to be the major challenges that researches come across while trying to improve the material properties of the composite [6]. They have noticed that the addition of surfactants to the CNTs is one of the techniques to overcome the agglomeration of the nanoparticles in the matrix. They act as coupling agents that introduce a repulsive force between the individual CNTs. These forces are larger in comparison with the van der Waals attractive forces of the CNTs. With low surfactant to multi walled carbon nanotubes (MWCNTs) ratio, the surfactant is unable to form an effective coating, which introduces an electrostatic repulsion (also called as steric hindrance effect) in order to counter-balance the van der Waals force of attractions [7]. Hence sufficient addition of surfactant becomes crucial.

Anionic surfactants are most commonly used for effective dispersion of CNTs. SDS, which is a well-known anionic detergent, has a unique property of binding forces, making it a suitable choice as a surfactant in the CNT filler materials. For good mechanical properties of the metal matrix material, a uniform dispersion of the nanoparticlesis necessary. In addition to this, the influence of sodium dodecyl sulfate (SDS) surfactant enhances the dispersion properties in the metal matrix composites [8,9]. Therefore, the 
study is focused on enhancing the mechanical properties of aluminium metal matrix composite along with uniform dispersion of surfactant coated on MWCNT.

\section{MATERIALS AND METHODS}

\subsection{Preparation of SDS Coated MWCNT}

The reinforced Al6065-MWCNT composites were fabricated using the stir casting method. The Aluminium 6065 ingots, casted as per the chemical composition represented in the Table 1, were used as the matrix material. MWCNT with respective properties of Shear modulus of $26 \mathrm{GPa}$, Young's Modulus of 1TPa, Poisson's ratio 0.33 and density of $1.3 \mathrm{~g} / \mathrm{cm}^{-2}$ were used.

Table 1: Composition of Aluminium 6065

\begin{tabular}{ccccccccccc}
\hline Component & Si & $\mathbf{C u}$ & $\mathbf{F e}$ & $\mathbf{Z n}$ & $\mathbf{M g}$ & $\mathbf{T i}$ & $\mathbf{M n}$ & $\mathbf{C r}$ & $\mathbf{P b}$ & Al \\
Amount (wt \%) & 0.6 & 0.36 & 0.3 & 0.1 & 1.0 & 0.1 & 0.1 & 0.1 & 0.08 & Balance \\
\hline
\end{tabular}

MWCNTs were later treated with an anionic SDS surfactant in a ratio of 1:1 with $300 \mathrm{ml}$ distilled water. This mixture was stirred continuously using a magnetic stirrer to obtain a homogeneous mixture. Furthermore, to ensure better homogenization, the mixture was subjected to ultra-sonication for 1 hour at room temperature as shown in Fig. 1(a).
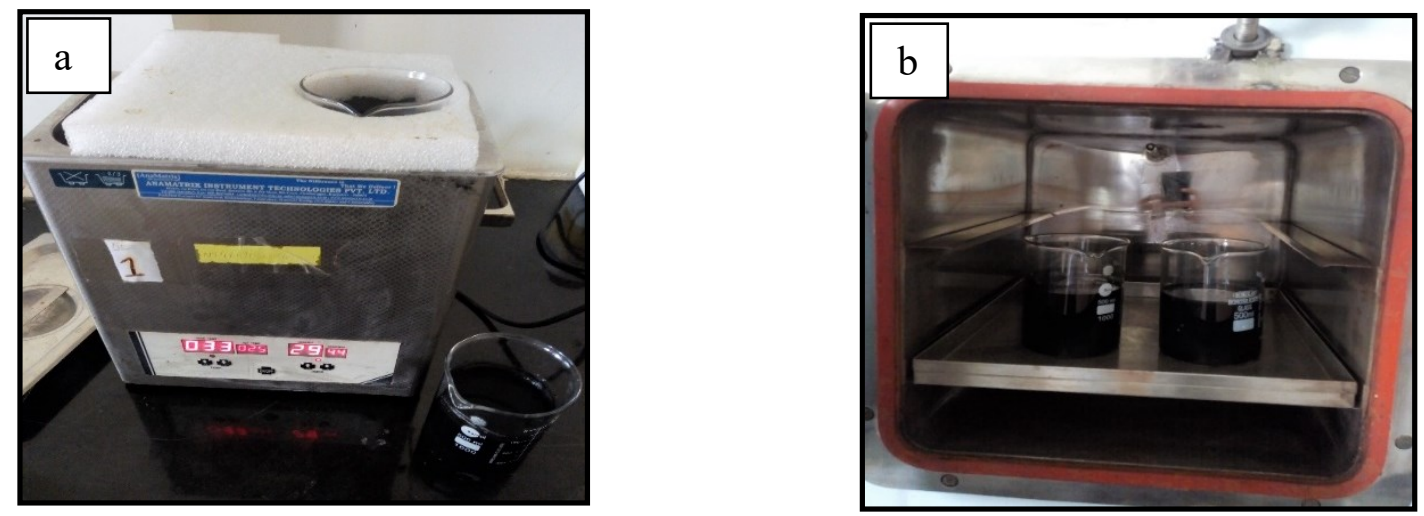

Fig. 1: (a) CNT-SDS mixture placed for ultra-sonication, (b) CNT-SDS mixture placed in hot air-oven at $80^{\circ} \mathrm{C}$.

Figure 1(b) shows the CNT-SDS mixture placed in a hot air oven to remove the water content at $80^{\circ} \mathrm{C}$ for 12 hours and to decrease the Van der Waals force between CNTs and to facilitate their ease of dispersion. The CNT-SDS flakes acquired after drying were grinded to obtain fine particles with the use of a mortar and pestle, as shown in Fig. 2. The final product obtained was stored in sealed container for further use. The products were later checked for FTIR analysis to examine the functional groups present in the product.

\subsection{Fabrication of MWCNT-Al Matrix}

The stir casting method is simple, highly efficient, and the most cost effective method for manufacturing of AMMCs in mass production. Thermodynamic factors like temperature, physical, metallurgical principles, and foundry techniques, are the most important factors involved in the conversion of metallic raw material(s) into composite materials using the stir casting method. The Al6065 ingot-castings were preheated and 
then placed into the electric furnace. The temperature of the crucible in the furnace is raised to $800^{\circ} \mathrm{C}$ and is maintained at the same temperature for uniform heating of the entire molten metal.

The molten metal was further stirred continuously for about 15 minutes to create a vortex and the SDS coated with CNT particulate were mixed as shown in Fig. 3(a, b). The same procedure is repeatedfor the reinforced material of $99 \%$ Al-6065 and 1 wt. \% of CNT without SDS coating. This takes place with a radial type stirrer with three wings that is moved down to a depth of $70 \mathrm{~mm}$ inside the furnace and is rotated with a speed of 500 rpm. This mixes the reinforced powder uniformly. The molten metal in the crucible was then degassed by adding a suitable amount of scum powder, which separates the impurities and accumulates at the surface. These impurities were later extracted and removed. During casting of aluminium, the solidification process involves the evolution of hydrogen gases that leads to porosity in the molten aluminium. The degassing is very much essential to produce high-quality castings $[10,11]$. In order to do this, solid dry hexachloroethane $\left(\mathrm{C}_{2} \mathrm{C}_{16}\right)$ degasser tablets were added, that remove the gases from the molten alloy; thus eliminating the presence of blow hole defects in the casting metal [12]. The molten metalwas later poured into the die to obtain three separate sample sets of MWCNT with and without SDS coating Reinforced-Al matrix composite as shown in Fig. 3.
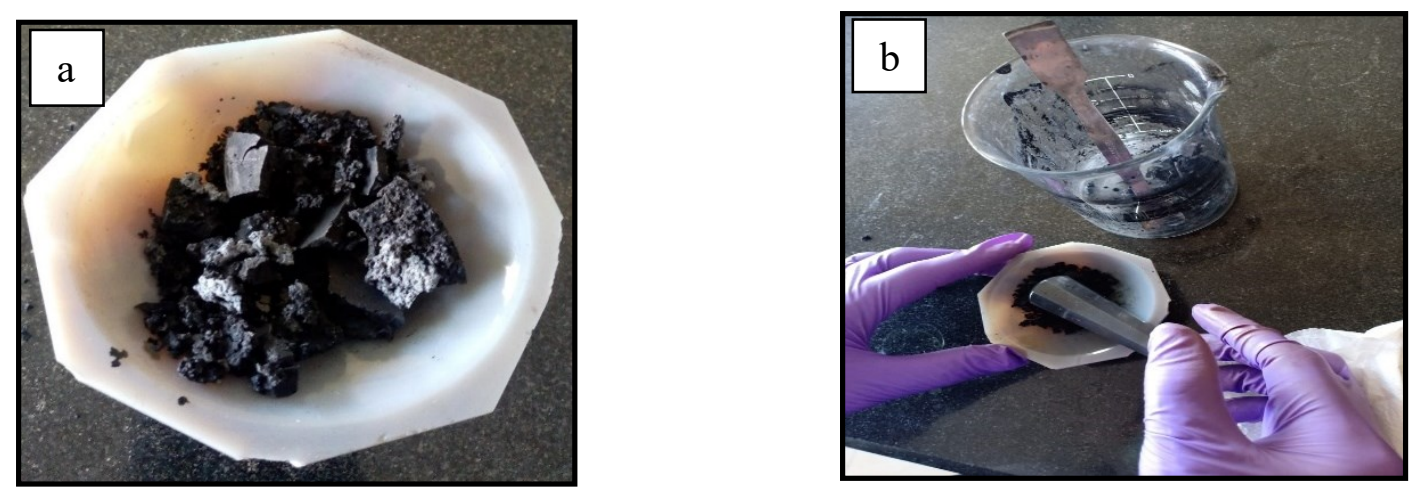

Fig. 2: (a) CNT-SDS flakes obtained after drying. (b) Powdering CNT-SDS flakes using a mortar and pestle.
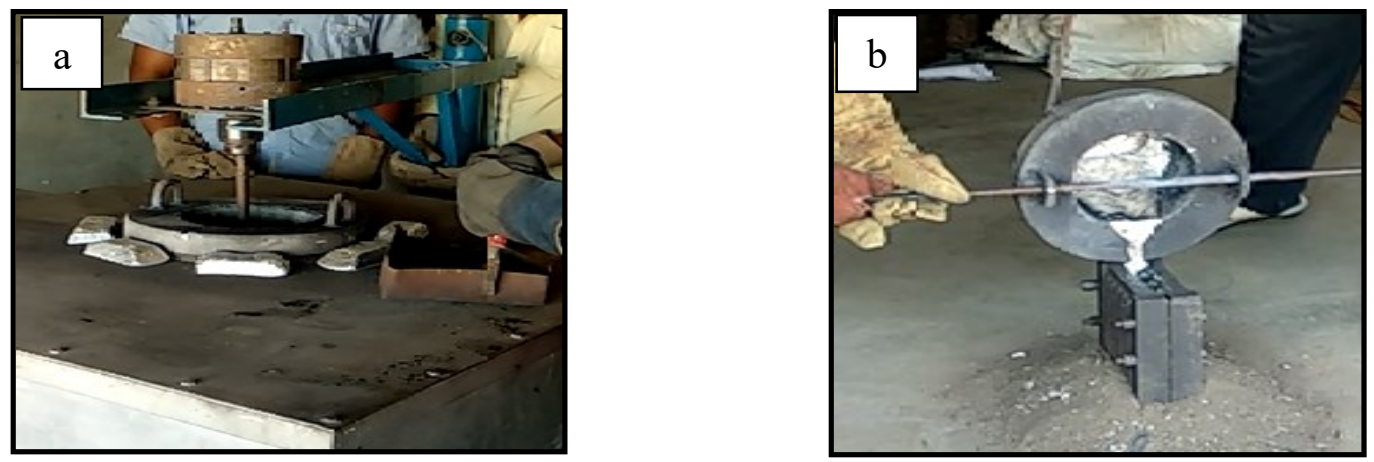

Fig. 3: (a) Stirring of molten metal and (b) Pouring the molten metal in to the die.

Figure 4 shows samples of aluminium ingots with SDS coated 1\% CNT and another non-SDS coated $1 \%$ MWCNT. The samples were later investigated for their microstructure, using SEM and radiography apparatus. 


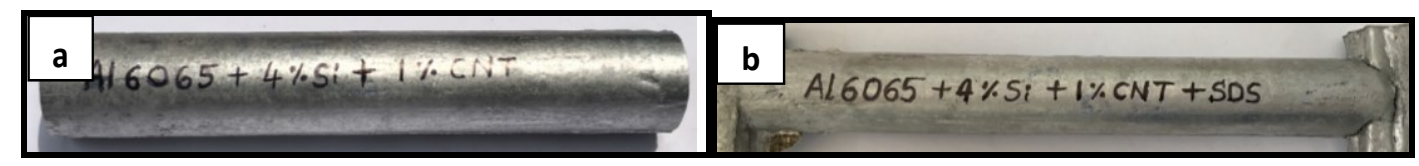

Fig. 4: (a) CNT+Al molten metal ingots with and (b) without SDS coating.

\section{RESULTS AND DISCUSSION}

\subsection{Fourier Transform Infrared Spectroscopy (FT-IR) Analysis of SDS Coated and Non-Coated CNT.}

FT-IR is one of the prominent analytical techniquesthatare used for identifying organic materials present in samples. It spots the chemical bonds in the molecules using an infrared absorption spectrum. This approach determines the transmission of infrared radiation into the sample material versus wavelength. The FT-IR results obtained confirmed the presence of SDS with CNT. The infrared absorption bands detect molecular components and structures. The presence of SDS substitution in the obtained sample is a significant data to be retrieved for the study and to evaluate the efficiency of the process.

The transmittance-comparison plot of CNT coated with SDS and CNT non-coated with SDS was plotted as shown in Fig. 5. It displays a peak around 1100, 1281, 2961, 2980 and $3445 \mathrm{~cm}^{-1}$. The peaks around 2961 and $2980 \mathrm{~cm}^{-1}$ are accredited to $\mathrm{C}-\mathrm{H}$ stretching frequencies. The band at $3445 \mathrm{~cm}^{-1}$ is allocated to stretch and bend vibrations of O-H bands due to absorbed water molecules. The band at $1281 \mathrm{~cm}^{-1}$ is attributed to $\mathrm{C}-\mathrm{H}$ bending frequencies. The peaks around $1100 \mathrm{~cm}^{-1}$ refer to the $\mathrm{SO}_{4}$ group, whereas these peaksare absent in non-coated MWCNT.

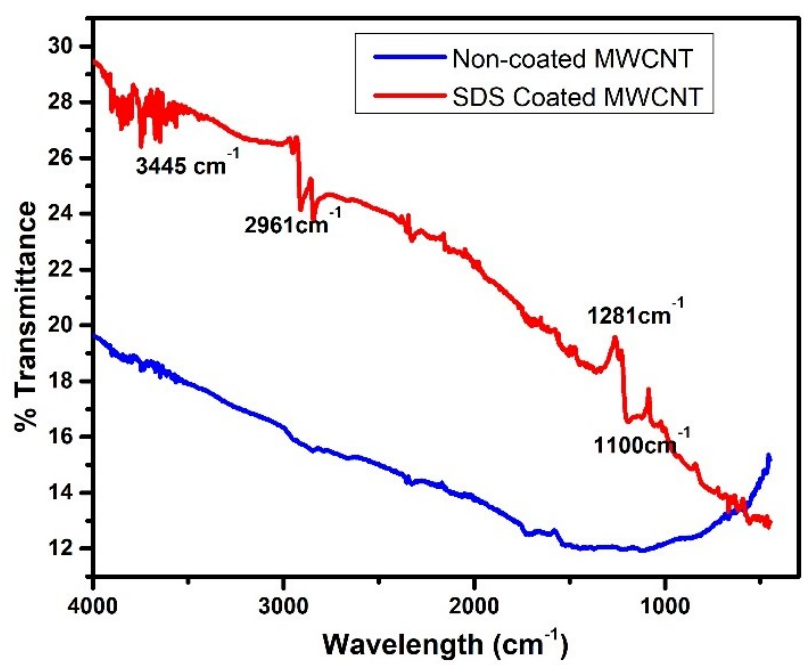

Fig. 5: Transmittance comparison plot for non-coated and SDS coated CNT.

\subsection{MicrostructureAnalysis}

The distribution of CNT nanotubes in the Al matrix was extensively analysed using SEM analysis. In Fig. 6(a) few distinct CNTs were detected for the untreated MWCNT-A1 matrix, which were entangled and overlapped together, whereas this arrangement differed for the MWCNT-Al matrix. This introduces defects in the Al matrix thus reducing the 
mechanical properties of the composite. In Fig. 6(b) the MWCNTs are seen discretely and effectively dispersed in the Al matrix.

The SEM image with the scale range of 500nm depicts the more porous structures for the non-coated Al matrix with uneven distribution of CNTs leading to the formation of clusters, as shown in Fig. 6(a). Inter-granular porosity is extensively observed with the absence of the SDS in the Al matrix [13]. Fewer porosities are observed and the porosity between the grains is not seen in Fig. 6(b) for the SDS coated MWCNT Al matrix. As shown in Fig.6(b), the quality of dispersion for MWCNT was enhanced with the help of added surfactant of a thin SDS layer. Thus, SEM analysis proves that SDS coated CNT dispersion when compared to non-coated CNT is better.
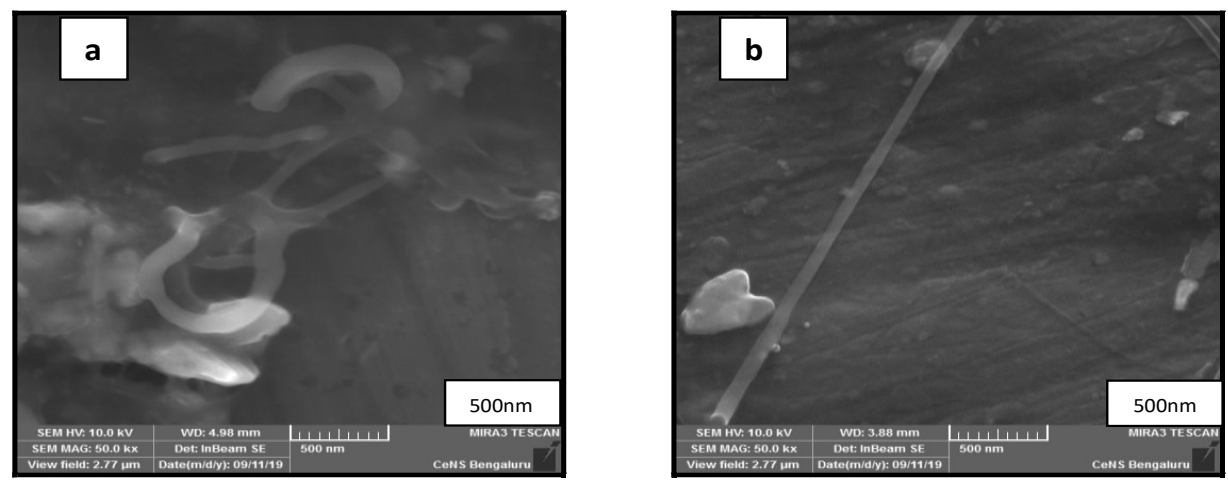

Fig. 6: (a) SEM image of MWCNT-Al matrix and (b) SDS-MWCNT-Al matrix.

\subsection{X-Ray Radiography}

Radiography is one of the best non-destructive methods to study the internal defects and volumetric discontinuities present in casting materials using radiography. This method is also implemented for non-planar materials.

Dark regions are observed in Fig. 7 (a), indicating that blow holes were formed in the non-coated MWCNT -Al matrix and it is insignificant in the SDS coated Al matrix. This defect might be the result of voids created during the casting process for the non-coated MWCNT-Al matrix. No cracks or fine lines were observed for both the non-coated and SDS coated MWCNT-Al matrix. Hence, it can be concluded that internal stress had less impact to cause cracks in the present specimens. Segregations are detected in the mid region for non-coated MWCNT-Al and this observation is absent in the SDS coated MWCNT-Al matrix.
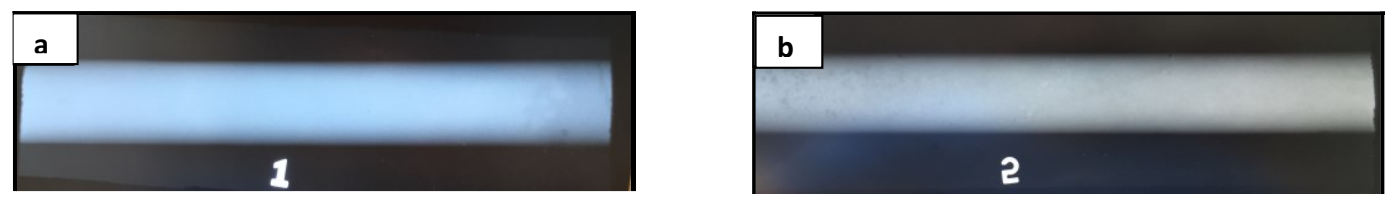

Fig. 7: (a) Radiography image of MWCNT-Al matrix and (b) SDS-MWCNT-Al matrix.

\subsection{Hardness Testing}

Specimens are tested for hardness using a Vickers Hardness testing machine. The Vickers hardness tester (Model-BV 250) follows ASTM E92 standards. Figure 8 shows the comparison plot of hardness for the non-coated and SDS coated MWCNT-Al matrix. It was evident that the SDS coated MWCNT-Al matrix showed a better average value of 
49.26 HV, than that of untreated MWCNT-Al matrix, which showed 45.23 HV. This significant improvement in the hardness might be ascribed to the solitary strengthening effect of nanotubes [14]. The percentage variation of hardness was increased by $8.91 \%$ for the SDS coated MWCNT-Al matrix.

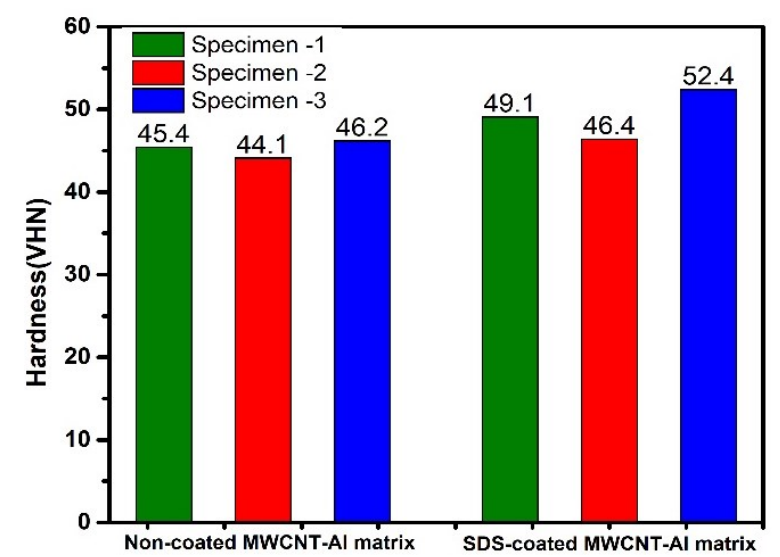

Fig. 8: Hardness comparison plot of non-coated and SDS coated MWCNT-Al matrix.

\subsection{Tensile Strength}

The tensile analysis was accomplished by the use of a Universal Tensile Testing Machine(UTM). Specimens were prepared as per ASTM E8 standards.From the graph in Fig. 9, it is evident that the tensile strength value is greater for the SDS coated MWCNT Al matrix. The excellent tensile strength value of the CNT contributes to significant improvement in tensile strength in Al matrix. The enhanced UTS values can be attributed to the presence of the well dispersed MWCNT that reduce the mobility of dislocations present in the matrix, thereby obstructing the plastic deformation. These results in remarkable progress in UTS percentage value of $7.48 \%$ for SDS coated MWCNT Al matrix.

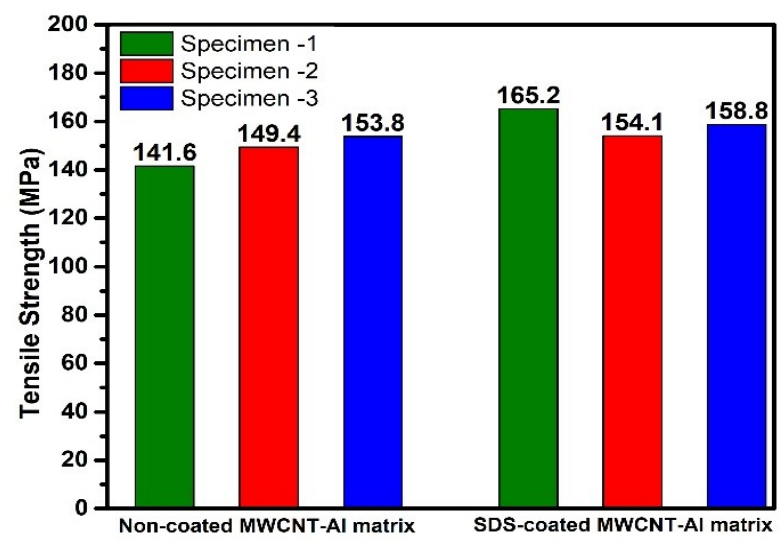

Fig. 9: Tensile strength comparison plot of non-coated and SDS coated MWCNT-Al matrix.

\subsection{Compressive Strength}

The compressive strength was tested by UTM according the ASTM E9 standards as shown in Fig. 10. The strength reduction in the non-coated MWCNT Al matrix may be due to the presence of agglomeration and clusters. 


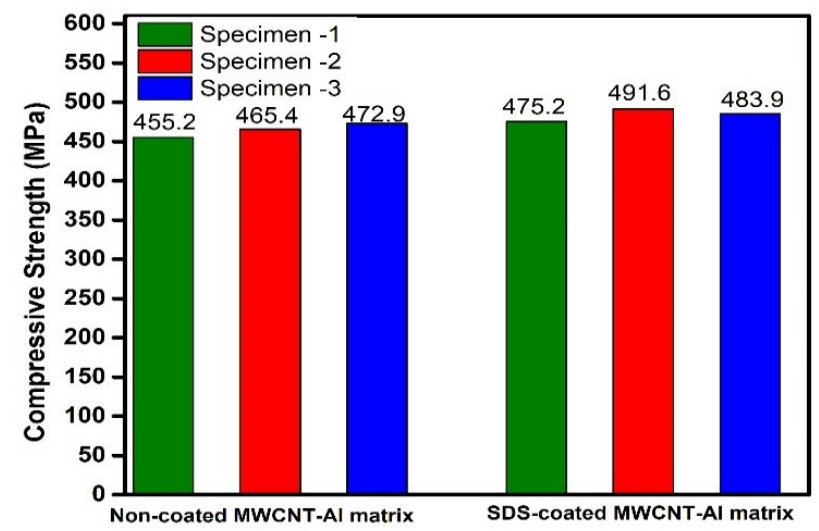

Fig. 10: Compressive strength comparison plot of non-coated and SDS coated MWCNT-Al matrix.

One of the main concerns for the reduced compression strength is the brittle behaviour of agglomerated CNTs so that the maximum strain was determined to be very low. The agglomeration in the non-coated MWCNT-Al matrix hindering the establishment of a dense sample in the course of densification process [15]. Consequently, the absence of clusters in the SDS coated MWCNT-Al matrix leads to 3.87\% increase in the compressive strength over the non-coated MWCNT Al matrix.

\subsection{Wear Analysis}

A computational approach called the pin on disc test was used to study the tribological condition of the MWCNT-Al Matrix. Per the ASTM G99 standards of specimens, $8 \mathrm{~mm}$ in diameter and $30 \mathrm{~mm}$ in length were taken into consideration. The plot in Fig. 11 displays the wear characteristics of SDS-coated and Non-coated MWCNT-Al matrix. The tests were carried out with a load of $5 \mathrm{kgs}$ and the specimen sliding on the disc at a rotation speed of $600 \mathrm{rpm}$. The amount of wear in microns was measured for a duration of $900 \mathrm{sec}$ and was plotted as a function of time, as indicated in Fig. 11.

The amount of wear of SDS coated MWCNT-Al matrix is lesser than non-coated matrix by $10.62 \%$. The graph indicates that the coated specimen gives uniform wear but non coated specimen gives abnormal fluctuations in the wear. This happens due to its poor wear resistance. The wear resistance (inverse of specific wear rate) of SDS-coated MWCNT-Al matrix was significantly improved by the homogeneous dispersion of MWCNT in Al matrix.

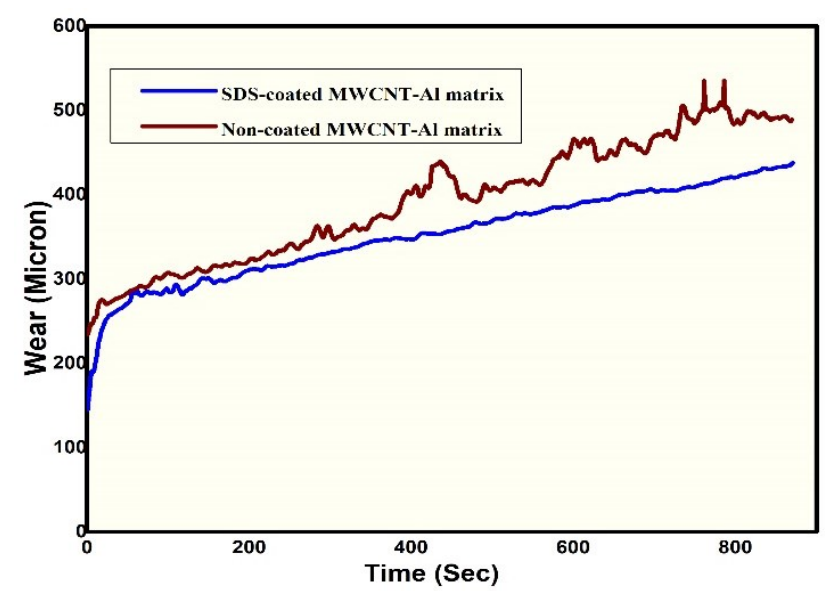

Fig. 11: Wear comparison plot of non-coated and SDS coated MWCNT-Al matrix. 


\subsection{Frictional Force}

Frictional force generated between two surfaces is mainly affected by the surface texture and amount of force impelling them together. Hence to evaluate the difference in the frictional force of the developed SDS coated and Non-Coated MWCNT-Al matrix, pin-on-disc test method was considered. The sliding took place under dry frictional conditions with normal load of $5 \mathrm{~kg}$; sliding velocities of $2.2 \mathrm{~m} / \mathrm{s}$ and for constant sliding distance of $1.98 \mathrm{~km}$. The test results of frictional force were reported as a function of time, indicated in Fig. 12.

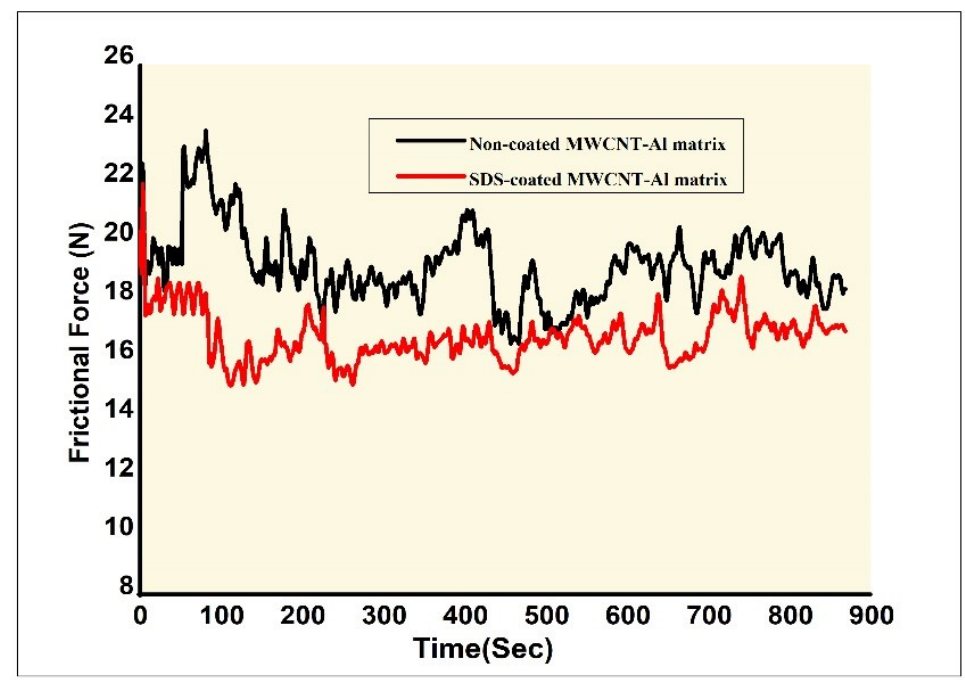

Fig. 12:Frictional force comparison plot of non-coated and SDS coated MWCNT-Al matrix.

As per the graph, the SDS coated MWCNT-Al matrix has better surface texture and offers high wear resistance as compared to that of the non-coated specimen. Thus, the SDS coated MWCNT-Al matrix offers reduced frictional force in comparison with that noncoated matrix and this reduces the amount of wear of the coated material.

\section{CONCLUSION}

The SDS-coated and non-coated MWCNT-Al MMC were fabricated. Tests on the specimens were conducted to study the dispersion of reinforcement in the base metal and further study extended to mechanical properties. The FT-IR study was conducted to ensure SDS coating on CNT. Radiography tests were conducted and observed that there were no traces of voids and blow holes in the SDS coated MWCNT-Al matrix. Fig. 5 exhibits that the infrared absorption percentage is more with the SDS coated MWCNT as compared to the non-coated MWCNT-Al MMCs. SEM tests for microstructure study were conducted. Figure $6 \mathrm{~b}$ shows that the SDS coated MWCNT-Al MMC found fairly good dispersion of reinforcement as compared to Fig. 6a, which is the non-coated MWCNT. Tensile strength, compression strength, wear rate, resistance to wear tests were conducted to study the mechanical properties. These tests were conducted on each of three specimens for each coated and non-coated MWCNT-Al MMC. It is observed that tensile strength and compression strength is increased to $7.48 \%$ and $4.1 \%$ respectively with SDS coated MWCNT-Al MMC. Figure 11 shows the wear rate evaluated at $900 \mathrm{sec}$ for the SDS coated MWCNT-Al MMC is about $10.62 \%$ less as compared to the non-coated MWCNT. 
Surface texture test were conducted and found (Fig. 12) that the coated MWCNT-Al MMC gives superior surface texture as compared to the non-coated MWCNT-Al MMC. The augmentation of dispersion and interfacial bonding of the SDS coated MWCNT-A1 composite, proves to be more effective in improving the wear resistance along with high tensile strength and compressive strength. It is evident from the study that the SDS coated MWCNT improves the dispersion of reinforcement in the Aluminium thereby improving the mechanical properties.

\section{ACKNOWLEDGEMENT}

We would like to thank the Research Centre, Department of Nano-Technology, Visvesvaraya Technological University, Chickaballapur, India for providing research facilities to carry out the research.

\section{REFERENCES}

[1] Esawi A., Morsi K (2007). Dispersion of carbon nanotubes (CNTs) in aluminum powder. Composites Part A. Applied Science and Manufacturing 38(2): 646-650.

DOI: 10.1016/j.compositesa.2006.04.006.

[2] Thomas S, Umasankar V(2019). Review of Recent Progress in the Development and Properties of Aluminum Metal Matrix Composites Reinforced with Multiwalled Carbon Nanotube by Powder Metallurgy Route, Materials Performance and Characterization, 8(3): 371-400. https://doi.org/10.1520/MPC20180140.

[3] Rajesh Jesudoss Hynes N, Sankaranarayanan R, Kathiresan M, Senthamaraikannan P, Khan A, Asiri A M, \& Khan I (2019). Synthesis, properties, and characterization of carbon nanotube-reinforced metal matrix composites. Nanocarbon and Its Composites, 805-830.

[4] F. Rikhtegar, S.G. Shabestari, H. Saghafian(2015). The homogenizing of carbon nanotube dispersion in aluminium matrix nanocomposite using flake powder metallurgy and ball milling methods.Powder Technology, 280: 26-34.

DOI: 10.1016/j.powtec.2015.04.047.

[5] Hanizam H, Salleh M S, Omar M Z, Sulong A. B(2019).Optimisation of mechanical stir casting parameters for fabrication of carbon nanotubes-aluminium alloy composite through Taguchi method. Journal of Materials Research and Technology, 8(2): 2223-2231.

DOI: $10.1016 /$ j.jmrt.2019.02.008.

[6] Awotunde M A, Adegbenjo A O, Ayodele O O, Okoro A M, Shongwe M B, Olubambi P A (2019). Interdependence of carbon nanotubes agglomerations, its structural integrity and the mechanical properties of reinforced nickel aluminide composites. J. Alloys and Compound,803:514-526. https://doi.org/10.1016/j.jallcom.2019.06.297.

[7] Li J, Fan T, Xu Y, Wu X(2016). Ionic liquids as modulators of physicochemical properties and nanostructures of sodium dodecyl sulfate in aqueous solutions and potential application in pesticide microemulsions. Physical Chemistry Chemical Physics, 18: 29797-29807. https://doi.org/10.1039/C6CP04722J.

[8] Hansen J H, Petersen S V, Andersen K K, Enghild J J, Damhus T, Otzen D(2009). Stable intermediates determine proteins primary unfolding sites in the presence of surfactants. Biopolymers, 91(3): 221-231.

Doi: 10.1002/bip.21125.

[9] Matarredona O, Rhoads H, Liu Z, Harwell J H, Balzano L, Resasco D E(2003). Dispersion of Single-Walled Carbon Nanotubes in Aqueous Solutions of the Anionic Surfactant NaDDBS, The Journal of Physical Chemistry B, 107:13357-13367. https://doi.org/10.1021/jp0365099. 
[10] Zhao L, Pan Y, Liao H, Wang Q(2012). Degassing of aluminum alloys during re-melting. Materials Letters, 66: 328-331.

https://doi.org/10.1016/j.matlet.2011.09.012.

[11] Haghayeghi R, Bahai H, Kapranos P(2012). Effect of ultrasonic argon degassing on dissolved hydrogen in aluminum alloy. Materials Letters, 82: 230-232. https://doi.org/10.1016/j.matlet.2012.05.112.

[12] Adat R, Kulkarni S, Kulkarni S(2015). Manufacturing of particulate reinforced aluminum metal matrix composites using stir casting process, International Journal of Current Engineering and Technology, 5(4):2808-2812.

[13] Shahrdami L, Sedghi A, Shaeri M H(2019). Microstructure and mechanical properties of Al matrix nanocomposites reinforced by different amounts of CNT and SiCW. Composites Part B: Engineerng, 175:107081. https://doi.org/10.1016/j.compositesb.2019.107081.

[14] Muhammad Mansoor, Muhammad Shahid(2016). Carbon nanotube-reinforced aluminum composite produced by induction melting, Journal of Applied Research and Technology 14(4): 215-224.

DOI: 10.1016/j.jart.2016.05.002.

[15] Jafari M, Abbasi M H, Enayati M H, Karimzadeh F(2012). Mechanical properties of nanostructured A12024-MWCNT composite prepared by optimized mechanical milling and hot pressing methods. Advanced Powder Technology., 23(2), 205-210. 